\author{
JURNAL RESPIRASI \\ JR \\ Vol. 3 No. 3 September 2017
}

\title{
Characteristics and the Side Effects of New MDR-TB Treatment in the Dr. Soetomo Hospital during 2016
}

\author{
Umi Fatmawati, Tutik Kusmiati \\ Departemen Pulmonologi dan Ilmu Kedokteran Respirasi, Fakultas Kedokteran Universitas Airlangga/RSUD Dr. Soetomo
}

\begin{abstract}
Background: The Multi Drug Resistance Tuberculosis (MDR-TB) prevalence rate is by 6900 in which there are $1.9 \%$ of new cases and $12 \%$ of cases fail. Indonesia ranks eighth out of 27 countries in the world. This study is aimed to investigate the characteristics of the new MDR TB patient demographic data, treatment, and side effects. Method: This research was analyzed retrospective data of the Medical Record (MR). Data were analyzed qualitatively. Results: The number of new patients are 82 people consisting of 41 men and 41 women. About 35 patients came from Surabaya and 47 were from outside Surabaya. Among those, 28 patients are 51-60 years old. Patients in the intensive phase (0-8 month) were 47 patient and 35 patients were in the continue phase 9-24 month. The main cause is the highest MDR-TB relapse 33 patients. Cycloserin and ethionamide prescribed to all of the subject followed by levofloxacin which is prescribed to 68 patients. The other medication were kanamycin, capreomycon, moxifloxacin and Para Amino Salicylat (PAS) which administered to 27,14,7 patient consecutively. Nausea is the one of the Adverse Drug reaction (ADR) that is preverly emerged. There were 30 patients complary this ADR and treatment which Omeprazole and Ranitidin. Conclusion: Characteristics of patients greatly differed between patients categories. In Soetomo hospital effort should be made to improve management case, drug and prevent or eliminate adverse drug reaction.
\end{abstract}

Keywords: MDR TB, patient characteristic, side effects

Correspondence: Umi Fatmawati, Departemen Pulmonologi dan Ilmu Kedokteran Respirasi, Fakultas Kedokteran Universitas Airlangga/RSUD Dr. Soetomo. Jl. Mayjen. Prof. Dr. Moestopo 6-8 Surabaya 60286. E-mail: arajekwesi@ gmail.com

\section{PENDAHULUAN}

WHO memperkirakan terdapat 450.000 orang menderita Multi Drug Resistance Tuberculosis (MDRTB) di seluruh dunia pada tahun 2012 dan 170.000 orang diantaranya meninggal dunia. Jumlah kasus meningkat pada tahun 2014 menjadi 480.000 orang. ${ }^{1}$ Pada tahun 2013 Indonesia menempati peringkat ke 8 dari 27 negara di dunia dengan perkiraan terdapat 6.900 kasus baru MDR-TB setiap tahun. Kasus MDR$T B$ diperkirakan terdiri dari $1,9 \%$ kasus TB baru dan $12 \%$ dari kasus TB yang pernah menjalani pengobatan ulang. ${ }^{2}$ Kasus $M D R-T B$ sering terlambat diagnosisnya sehingga resistensi yang terjadi semakin berkembang. Diperlukan diagnosis dan penanganan yang segera terhadap pasien $M D R-T B .^{3}$ Adanya resistensi Obat
Anti Tuberkulosis (OAT) yang mengawali terjadinya $M D R-T B$ dibuktikan dengan pemeriksaan uji kepekaan Mycobacterium tuberculosis dengan metode tes cepat (rapid test) dan metode konvensional. Saat-Saat ini di Indonesia hanya ada satu tes cepat molekuler yang dapat digunakan untuk mengetahui resistensi terhadap OAT yaitu GeneXpert. Pemeriksaan LPA (Line Probe Assay) belum dapat dilakukan di Indonesia. Sedangkan metode konvensional yang digunakan adalah kultur dengan media Lowenstein Jensen dan MGIT (Mycobacteria Growth Indicator Tube).

Definisi MDR-TB adalah Mycobacterium tuberculosis yang resisten terhadap OAT lini pertama yang paling efektif yakni Isoniazid atau Rifampisin. ${ }^{4}$ Resistensi dapat terjadi karena adanya mutasi pada gen kromosom bakteri, ataupun adanya toleransi obat karena perubahan 
epigenetik pada ekspresi gen dan modifikasi protein yang menyebabkan bakteri menjadi toleran terhadap OAT. ${ }^{5,6}$ Resistensi pada isoniazid terjadi pada gen katG dan inhA atau pada daerah promotor dan resistensi rifampisin terjadi pada daerah hot spot $81 \mathrm{bp} \mathrm{rpoB.}{ }^{7}$ Pengobatan $M D R-T B$ terdiri atas obat lini-kedua dengan program pengobatannya menggunakan strategi pengobatan yang standard (standardized treatment). Klasifikasi pemberian OAT pada pasien menurut WHO dibagi menjadi 4 kelompok terdapat pada tabel 1.

Paduan OAT yang diberikan kepada semua pasien dengan diagnosa $M D R-T B$ menurut Kementerian Kesehatan RI adalah Km - Lfx - Eto - Cs - Z - (E) / Lfx - Eto - Cs - Z - (E) dimana pada fase intensif (fase awal) diberikan OAT Kanamisin, Levofloxacin, Etionamid, Sikloserin, Pirazinamid, dan Etambutol, sedangkan pada fase lanjutan yaitu diberikan OAT mengikuti fase intensif kecuali Kanamisin., ${ }^{2,9-11}$

Berdasarkan uraian diatas, kami ingin menganalisa dan mengkaji karakteristik, efek samping dan pengobatan pasien MDR TB baru yang ditemukan selama tahun 2016 di Rumah Sakit Dr. Soetomo Surabaya.

Tabel 1. Klasifikasi Pemberian OAT pada Pasien Menurut WHO Tahun $2014 .^{8}$

\begin{tabular}{|c|c|c|c|}
\hline Group & Class of Drugs & & Drugs \\
\hline \multirow[t]{3}{*}{ Group A } & Fluoroquinoloes & & Levofloxacin \\
\hline & & & Moxifloxacin \\
\hline & & & Gatifloxacin \\
\hline \multirow[t]{3}{*}{ Group B } & $\begin{array}{l}\text { Secound-line } \\
\text { injectables }\end{array}$ & & Kanamycin \\
\hline & & & Amikacin \\
\hline & & & Capreomycin \\
\hline Group C & $\begin{array}{l}\text { Other core } \\
\text { secound-line } \\
\text { agents }\end{array}$ & & $\begin{array}{l}\text { Ethionamide/ } \\
\text { Prothionamide, } \\
\text { Cycloserine/ } \\
\text { Terizidone, } \\
\text { Linezolid, } \\
\text { Clofazimine }\end{array}$ \\
\hline \multirow[t]{10}{*}{ Group D } & Add-on agents & D1 & Pyrazinamide \\
\hline & & & Ethambutol \\
\hline & & & High-dose isoniazid \\
\hline & & D2 & Bedaquiline \\
\hline & & & Delamanid \\
\hline & & D3 & $\begin{array}{l}\text { P-aminosalicylic } \\
\text { acid }\end{array}$ \\
\hline & & & Imipenem-cilastatin \\
\hline & & & Meropenem \\
\hline & & & $\begin{array}{l}\text { Amoxicillin- } \\
\text { clavulunate }\end{array}$ \\
\hline & & & Thioacetazone \\
\hline
\end{tabular}

\section{METODE}

Penelitian ini termasuk penelitian observasional dengan menggunakan data retrospektif. Lokasi penelitian adalah di Poli MDR-TB RSUD Dr. Soetomo Surabaya. Waktu pengambilan data dilakukan pada bulan FebruariMaret 2017. Populasi penelitian ini adalah semua pasien yang terdiagnosis $M D R-T B$ serta menjalani rawat jalan di Poli MDR-TB RSUD Dr. Soetomo Surabaya. Sampel penelitian ini adalah pasien yang terdiagnosis $M D R-T B$ yang menjalani pengobatan rawat jalan dan sesuai dengan kriteria inklusi dalam periode 1 Januari 2016 sampai 31 Desember 2016. Pengambilan sampel dilakukan dengan metode time limit sampling,

Data penelitian didapatkan dari RM pasien yang meliputi identitas pasien, riwayat TB pasien, terapi yang didapatkan meliputi pemilihan obat, kombinasi terapi, regimen dosis, lama terapi, efek samping, terapi untuk mengatasi efek samping obat kemudian dituliskan ke dalam Lembar Pengumpul Data (LPD) untuk kemudian dilakukan analisis secara diskriptif.

\section{HASIL}

Berdasarkan data yang telah diperoleh selama periode waktu 1 Januari 2016-31 Desember 2016 didapatkan total 82 pasien MDR-TB dengan distribusi yang dijelaskan pada Tabel 2.

Berdasarkan paparan pada tabel 2 dapat dilihat bahwa kasus $M D R-T B$ antara laki-laki dan perempuan memiliki jumlah yang sama. Hal ini menunjukkan bahwa kasus $M D R-T B$ dapat menyerang baik pada laki-laki maupun perempuan. Jumlah kasus $M D R-T B$ cenderung meningkat seiring dengan penambahan usia pasien yaitu sebanyak $34,1 \%$ pada umur 31-50 tahun dan meningkat sebanyak 47,6\% pada umur $>50$ tahun. Ditinjau dari asal daerah, jumlah pasien $M D R-T B$ dari luar Surabaya menyumbang jumlah kasus paling besar yaitu 57,3\% akan tetapi hampir setengah dari jumlah kasus tersebut berasal dari Kota Surabaya yaitu sebesar $42,7 \%$.

Tabel 2. Distribusi Pasien MDR-TB berdasarkan Jenis Kelamin, Umur dan Asal Daerah Tahun 2016

\begin{tabular}{llll}
\hline Distribusi & \multicolumn{1}{c}{ Kategori } & $\begin{array}{c}\text { Jumlah } \\
(\mathbf{n})\end{array}$ & $\begin{array}{c}\text { Persentase } \\
(\%)\end{array}$ \\
\hline Jenis & Laki-laki & 41 & $50,0 \%$ \\
Kelamin & Perempuan & 41 & $50,0 \%$ \\
\hline Usia & <30 Tahun & 15 & $18,3 \%$ \\
& 31-50 Tahun & 28 & $34,1 \%$ \\
& > 50 Tahun & 39 & $47,6 \%$ \\
\hline Asal & Surabaya & 35 & $42,7 \%$ \\
Daerah & Luar Surabaya & 47 & $57,3 \%$ \\
\hline
\end{tabular}




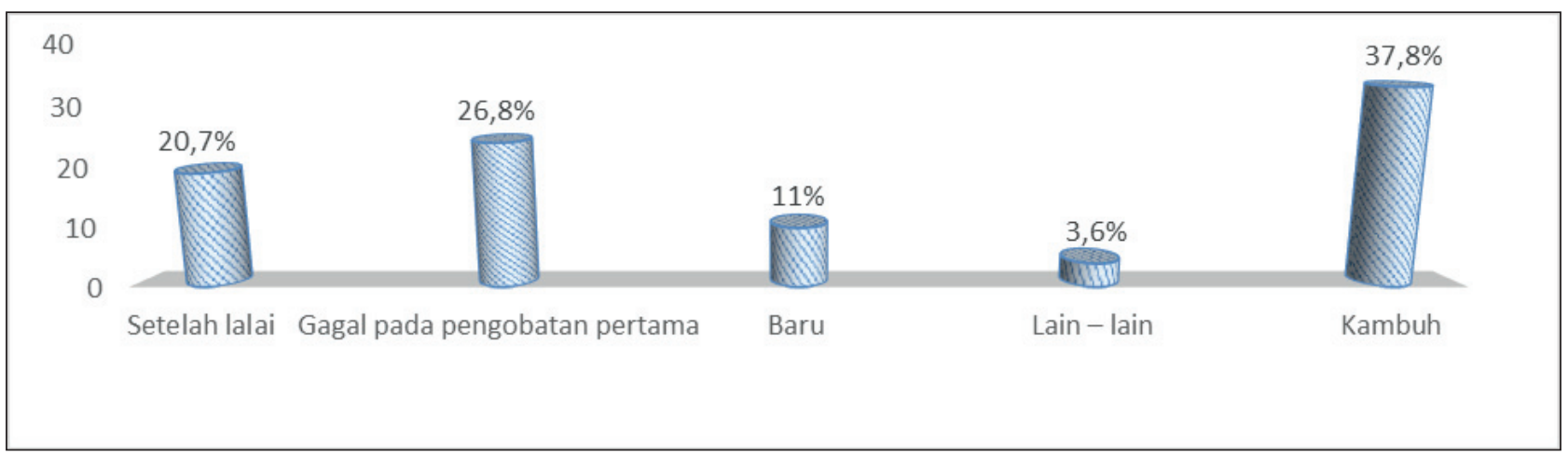

Gambar 1. Data MDR-TB Periode Tahun 2016 Berdasarkan Kategori Kasus Pasien

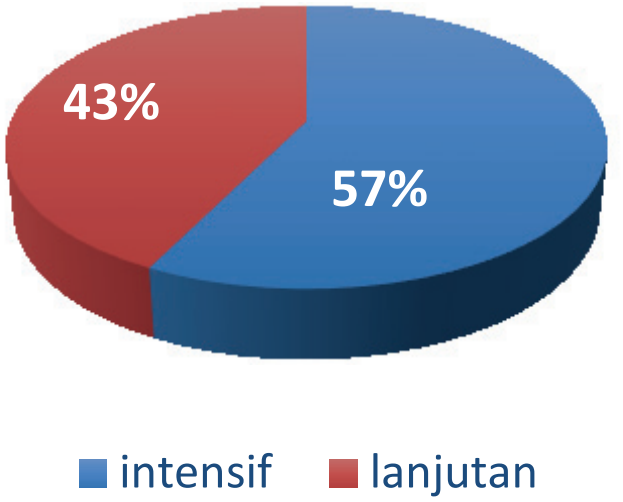

Gambar 2. Fase pengobatan pasien MDR-TB

Kasus MDR-TB dapat dikelompokkan dalam 5 kategori yaitu: 1) Setelah lalai; 2) Gagal pengobatan pertama; 3) Kasus Baru; 4) Lain-lain dan 5) Kasus Kambuh. Hasil pengamatan kasus MDR-TB pada rentang periode tahun 2016 di RSUD Dr. Soetomo Surabaya dapat dilihat pada Gambar 1.

Berdasarkan hasil penelitian yang ditunjukkan dalam Gambar 1 didapatkan bahwa kasus MDR-TB terbanyak adalah kategori kasus kambuh yaitu sebanyak 37,8\%. Ada sekitar seperempat kasus $M D R-T B$ terkategori gagal pada pengobatan pertama yaitu $26,8 \%$. Selain itu ada $11 \%$ kasus $M D R-T B$ yang merupakan kasus baru.

Fase pengobatan pasien MDR-TB dibagi menjadi 2 fase yaitu: 1) fase pengobatan pasien intensif 0-8 bulan; dan 2) fase lanjutan 9-24 bulan. Berdasarkan hasil penelitian, pengobatan pasien $M D R-T B$ paling banyak terjadi pada fase pengobatan intensif $0-8$ bulan yaitu sejumlah 57\%. Fase pengobatan pasien MDR-TB periode dapat dilihat pada Gambar 2.

Setiap pengobatan terdapat beberapa efek samping yang berbeda antar pasien. Beberapa efek samping yang ditemukan pada pengobatan kasus MDR-TB periode tahun 2016 di RSUD Dr. Soetomo dapat dilihat pada Tabel 2.
Tabel 2. Efek samping yang di alami pasien $M D R-T B$

\begin{tabular}{clcc}
\hline No & \multicolumn{1}{c}{ Efek Samping } & $\begin{array}{c}\text { Jumlah } \\
(\mathbf{n})\end{array}$ & $\begin{array}{c}\text { Persentase } \\
(\%)\end{array}$ \\
\hline 1. & Mual & 30 & 36,58 \\
2. & Muntah & 30 & 36,58 \\
3. & Peningkatan Asam Urat & 21 & 25,60 \\
& (Hiperuricemia) & & \\
4. & Rash / gatal / alergi & 18 & 21,95 \\
5. & Panas / meriang & 16 & 19,51 \\
6. & Nyeri sendi / Athralgia / & 13 & 15,85 \\
& Myalgia & & \\
7. & Hipokalemia & 9 & 10,97 \\
8. & Diare & 6 & 7,32 \\
9. & Cemas (tidak bisa tidur) & 4 & 4,88 \\
10. & Pengingkatan QT prolong & 3 & 3,66 \\
& / Aritmia & & \\
11. & Telinga berdenging & 3 & 3,66 \\
12. & Lemah / lemas & 2 & 2,44 \\
13. & Hiperkalemia & 2 & 2,44 \\
14. & Pusing berputar (vertigo) & 1 & 1,22 \\
15. & Sariawan & 1 & 1,22 \\
\hline
\end{tabular}

$\mathrm{NB}=$ satu pasien bisa mengalami lebih dari satu efek samping dan bisa mendapatkan lebih dari satu obat untuk pengatasan efek sampingnya tersebut

Data pada Tabel 2 menjelaskan bahwa pasien dapat mengalami lebih dari satu efek samping. Efek samping yang sering dialami oleh sebagian besar pasien $M D R$ $T B$ saat pengobatan adalah mual dan muntah yaitu sebanyak $36,58 \%$ pasien. Efek samping selanjutnya yang juga sering dialami oleh banyak pasien MDR-TB adalah peningkatan asam urat yaitu sebanyak $25,60 \%$ pasien. Menyusul efek samping selanjutnya yang sering dialami oleh pasien adalah rash/ gatal/ alersi sebanyak $21,95 \%$ total pasien. Beberapa efek samping lainnya hanya dialami oleh sebagian kecil pasien.

Guna menurunkan efek samping akibat pengobatan $M D R-T B$ tersebut maka diberikan terapi obat sesuai kebutuhan pasien. Tabel 3 berikut dapat menjelaskan 
Tabel 3. Terapi untuk mengatasi efek samping yang diterima pasien

\begin{tabular}{|c|c|c|c|}
\hline No & Nama obat & $\begin{array}{c}\text { Jumlah } \\
(n)\end{array}$ & $\begin{array}{c}\text { Persentase } \\
(\%)\end{array}$ \\
\hline 1. & Omeprazole & 30 & 36,58 \\
\hline 2. & Ranitidine & 30 & 36,58 \\
\hline 3. & Allopurinol tab & 21 & 25,60 \\
\hline 4. & Domperidon & 18 & 21,95 \\
\hline 5. & Cetirizin & 16 & 19,52 \\
\hline 6. & Paracetamol & 14 & 17,07 \\
\hline 7. & $\begin{array}{l}\text { Kalium Sustained Release } \\
\text { / KSR }\end{array}$ & 9 & 10,97 \\
\hline 8. & Ondancetron & 7 & 8,53 \\
\hline 9. & Meloxicam & 6 & 7,32 \\
\hline 10. & Antasida Syrup & 5 & 6,09 \\
\hline 11. & New Diatabs & 5 & 6,09 \\
\hline 12. & Asam Mefenamat & 5 & 6,09 \\
\hline 13. & Amitriptiline & 4 & 4,88 \\
\hline 14. & Tebokan Special & 3 & 3,66 \\
\hline 15. & Mecobalamin & 3 & 3,65 \\
\hline 16. & Bisoprolol & 2 & 2,44 \\
\hline 17. & Vitamin B Kompleks & 2 & 2,44 \\
\hline 18. & Simvastatin & 2 & 2,44 \\
\hline 19. & $\begin{array}{l}\text { Calsium Polystyrene } \\
\text { Sulfonate / Kalitake }\end{array}$ & 2 & 2,44 \\
\hline 20. & Natrium Diclofenac & 2 & 2,44 \\
\hline 21. & Ibuprofen & 2 & 2,44 \\
\hline 22. & Prednison & 1 & 1,22 \\
\hline 23. & Gentamycin & 1 & 1,22 \\
\hline 24. & Metoclopramide & 1 & 1,22 \\
\hline 25. & Loperamide & 1 & 1,22 \\
\hline 26. & Mertigo & 1 & 1,22 \\
\hline 27. & Amiodaron & 1 & 1,22 \\
\hline 28. & Ketokonazole & 1 & 1,22 \\
\hline 29. & Sucralfat Syr & 1 & 1,22 \\
\hline 30. & Garamycin & 1 & 1,22 \\
\hline
\end{tabular}

$\mathrm{NB}=$ terapi obat diberikan kepada sesuai dengan efek samping yang dialami oleh pasien

terapi obat apa saja yang diberikan kepada pasien $M D R$ $T B$ untuk menurunkan efek samping akibat pengobatan. Tabel 3 memperlihatkan bahwa terapi efek samping terbanyak adalah omeprazole dan ranitidine 30 pasien $(36,58 \%)$, kemudian allopurinol 21 pasien $(25,61 \%)$.

\section{PEMBAHASAN}

Berdasarkan data yang di peroleh, selama periode tahun 2016 di dapatkan jumlah pasien sebanyak 82 pasien dengan rincian sebanyak 41 pasien dengan jenis kelamin laki laki dan 41 pasien dengan jenis kelamin perempuan (Tabel 1). Hasil penelitian ini berbeda dengan penelitian yang dilakukan oleh Elmi, dimana penderita $M D R-T B$ lebih banyak didapatkan pada jenis kelamin laki-laki daripada perempuan. Kecenderungan untuk merokok dan mengonsumsi alkohol menjadi salah satu faktor penyebab $M D R-T B$ lebih banyak ditemui pada laki-laki. ${ }^{12}$ Merokok dan mengkonsumsi alkohol merupakan gaya hidup yang dapat mengakibatkan menurunnya daya tahan tubuh sehingga lebih mudah terinfeksi bakteri TB.

Data distribusi usia pada pasien $M D R-T B$ dapat dilihat pada Tabel 1. Rentang usia pasien paling sedikit adalah pada usia $<30$ tahun yaitu $18,3 \%$ dan meningkat seiring pertambahan usia yaitu $34,1 \%$ pada usia 31-50 tahun dan paling tinggi pada usia $>50$ tahun yaitu sebanyak 47,6\%. Hasil penelitian ini tidak selaras dengan penelitian yang dilakukan oleh Skrahina, yaitu didapatkan pasien $M D R-T B$ tertinggi pada usia dibawah 24-44 tahun dibandingkan pasien 45-64 tahun. ${ }^{13}$ Faktor yang diduga mengakibatkan tingginya $M D R-T B$ pada usia 51-60 tahun yaitu orang usia tua / geriatric yang tidak produktif lagi, tidak banyak bersosialisasi dengan lingkungan dan memiliki imunitas yang rendah, sehingga lebih mudah terinfeksi TB maupun tertular melalui kontak dengan penderita TB. ${ }^{11}$ Namun, penelitian ini berbeda dengan penelitian yang dilakukan oleh Elmi dkk, dimana pasien MDR-TB tertinggi pada usia 45-64 tahun dan yang kedua pada usia 25-44 tahun. Pasien usia 45-64 tahun dan usia di atas 65 tahun. Menurut penelitian tersebut, pasien $M D R-T B$ paling banyak pada kelompok usia 45-64 tahun yang lebih mudah terserang $M D R-T B$ sedangkan pada kelompok 25-44 tahun merupakan kelompok yang lebih beresiko terkena $M D R-T B$, dimana pada usia ini resiko yang di alami lebih bervariasi, antara lain produktivitas tinggi, lebih banyak bersosialisasi dengan lingkungan. ${ }^{12}$

Berdasarkan data yang di peroleh, didapatkan domisili pasien MDR-TB tahun 2016 terbanyak berasal dari luar Surabaya sebesar $57,3 \%$ pasien sedangkan yang berasal dari Surabaya sebesar $42,7 \%$ pasien (Tabel 1). Hal ini dikarenakan untuk pasien $M D R-T B$ baru perlu di lakukan observasi mulai dari pemeriksaan klinis, pemeriksaan penunjang laboratorium, pemilihan obat, penentuan dosis apakah harus di lakukan eskalasi, deskalasi atau intermiten dan monitoring efek samping selama 2 minggu di lakukan di Rumah Sakit Dr.Soetomo.

Kategori kasus $M D R-T B$ yang tertinggi adalah kambuh atau relaps sebanyak $37,8 \%$ diikuti gagal pada pengobatan pertama sebesar 26,8\% (gambar 4). Kambuh atau relaps ini bisa di sebabkan oleh beberapa faktor diantaranya ketidakpatuhan pasien dalam mengkonsumsi obat, efek samping yang muncul dan menyebabkan rasa tidak nyaman pada pasien, pemilihan regimen OAT yang tidak tepat, dosis yang tidak adekuat, pasien berhenti minum obat dikarenakan kondisi klinis sudah membaik ataupun resistensi alami yang ditimbulkan oleh kuman $M D R-T B$ itu sendiri. Menurut WHO, kasus kekambuhan dapat menyebabkan resistensi OAT sebagai akibat dari penggunaan obat yang tidak menentu. Peristiwa ke kambuhan juga dapat dipengaruhi oleh sistem imun pasien yang rendah karena kurangnya kebersihan 
lingkungan dan adanya kontak dengan pasien TB maupun $M D R-T B$ lainnya. ${ }^{11}$

Tabel 1 juga menunjukkan pasien yang mengalami kambuh TB sebesar 37,8\%. Hasil ini mendukung alasan bahwa kekambuhan dapat menjadi faktor seorang penderita TB yang telah sembuh dapat kembali terinfeksi TB bahkan menjadi $M D R-T B$. Sementara itu, pasien yang gagal pengobatan TB paru adalah pasien dengan hasil pemeriksaan dahak tetap positif atau kembali menjadi positif pada bulan kelima atau lebih selama pengobatan atau kapan saja apabila selama dalam pengobatan diperoleh hasil laboratorium yang menunjukkan adanya resistensi OAT. Kegagalan pengobatan yang cukup tinggi merupakan identifikasi awal terjadinya resistensi obat. Resistensi OAT dipicu oleh mutasi pada bakteri TB, sehingga pasien yang telah dinyatakan sembuh pun kemudian dapat terdiagnosa menjadi $M D R-T B$. Kegagalan pengobatan dipengaruhi oleh ketidakpatuhan pasien, tingginya beban infeksi mikobakteria yang ditunjukkan dengan kavitas, regimen pengobatan yang kurang sesuai, masalah sosio-ekonomi, kurangnya pengetahuan, adanya efek samping, dan penyakit penyerta. ${ }^{14}$

Terdapat dua fase pada pengobatan $M D R-T B$ yaitu fase intensif dan fase lanjutan. Pada fase intensif pasien mendapatkan injeksi aminoglikosida yaitu Capreomycin atau Kanamycin yang di berikan secara im (intra muscular). Durasi pengobatan fase intensif ini masingmasing pasien berbeda antara 6-8 bulan tergantung kepatuhan untuk injeksi. Sedangkan pada fase lanjutan pasien tidak mendapatkan injeksi aminoglikosida dan berlangsung selama 10-16 bulan. Total keseluruhan antara fase intensif dan fase lanjutan adalah 18-24 bulan. Dari data ini di dapatkan pasien dengan fase pengobatan intensif $0-8$ bulan sebesar 47 pasien sedangkan fase lanjutan 9-24 bulan sebanyak 35 pasien (gambar 5). Salah satu faktor yang berpengaruh terhadap keberhasilan terapi $M D R-T B$ yaitu lama pengobatan pasien. Pengobatan $M D R-T B$ dinyatakan selesai tepat waktu jika berlangsung minimal selama 18 bulan hingga terjadi konversi biakan, dan maksimal 24 bulan. Pasien yang telah menjalani pengobatan tepat waktu menunjukkan kepatuhan yang baik.

Beberapa faktor yang menyebabkan pengobatan lebih lama yaitu karena kurangnya pengetahuan tentang bahaya TB, tidak ada dukungan keluarga, adanya efek samping, maupun penyakit penyerta yang mengakibatkan ketidakpatuhan. Pasien yang tidak datang pada jadwal minum obat yang telah ditentukan harus menjalani pengobatan lebih lama karena harus memenuhi target minum obat yang telah ditentukan oleh TAK. Selain itu, pengobatan yang lebih lama dapat mengakibatkan berlanjutnya resistensi OAT tertentu, sehingga kombinasi OAT yang digunakan dapat berubah dan potensi efek samping yang timbul akan semakin besar. Efek samping oleh OAT sangat banyak sehingga pasien $M D R-T B$ merasa tidak nyaman dengan pengobatan yang dijalani, sedangkan penyakit penyerta dapat memperberat kondisi pasien sehingga pengobatan dapat menjadi lebih lama. ${ }^{15,16}$

Pasien $M D R-T B$ yang menjalani pengobatan pada umumnya mengalami efek samping akibat OAT yang digunakan. Salah satu efek samping maupun keluhan yang paling sering ditimbulkan selama menjalani pengobatan $M D R-T B$ yaitu mual muntah sebanyak 30 pasien dengan terapi yang di terima omeprazole dan ranitidine. Hampir semua OAT MDR-TB ini efek sampingnya adalah gangguan GIT diantaranya mual muntah. Efek samping dengan gangguan GIT terberat adalah Pirazinamide. Selain itu efek samping kedua yang sering muncul adalah hiperuricemia (peningkatan asam urat). Efek samping hiperuricemian ini dapat di akibatkan oleh karena penggunaan kombinasi ethambutol dan pirazinamide. Pirazinamid merupakan agen retensi asam urat yang kuat yang menyebabkan lebih dari $80 \%$ reduksi klirens renal asam urat pada dosis 300 mg sehari, sedangkan Etambutol meningkatkan asam urat dengan menurunkan klirens terhadap asam urat. Namun, Etambutol memiliki kekuatan yang lebih kecil dan kurang konsisten untuk meningkatkan asam urat jika dibandingkan dengan Pirazinamid. ${ }^{17}$ Terapi yang di terima pasien untuk mengatasai hiperuricemia ini adalah allopurinol. Sebanyak 21 pasien yang mengalami efek samping hiperuricemia. Gangguan pendengaran dapat disebabkan oleh OAT golongan aminoglikosida, yaitu Kanamisin dan Kapreomisin. Beberapa pasien telah mengalami gangguan pendengaran sebelum menjalani pengobatan $M D R-T B$, yang dapat disebabkan oleh paparan obat aminoglikosida lainnya, contohnya streptomisin, yang kemudian semakin diberatkan oleh Kanamisin.

Obat Anti Tuberkulosis (OAT) aminoglikosida dapat menyebabkan akumulasi pada bagian dalam telinga karena konsentrasinya yang tinggi dalam plasma. Akumulasi ini mengakibatkan kerusakan yang progresif pada sel sensori vestibular maupun koklea, dan bersifat irreversible. ${ }^{18}$ Paparan aminoglikosida ini menyebabkan mutasi pada DNA mitokondria yang merusak translasi RNA dalam mitokondria melalui interaksi dengan daerah ikatan pada mitokondria. Kemudian, terjadi penurunan sintesis protein yang menghasilkan ototoksik. ${ }^{19}$ Ototoksik akibat kanamisin terjadi pada koklea yang ditandai dengan berkurangnya kemampuan pendengaran atau terjadi tinnitus. Bahaya gangguan pendengaran pada pasien yang menerima kanamisin maupun kapreomisin telah disadari sejak awal, sehingga sebelum memulai pengobatan pasien menjalani pemeriksaan audiometri yang dilakukan secara rutin sampai pengobatan selesai. Selain gangguan pendengaran, Kanamisin dan Kapreomisin merupakan OAT yang bersifat nefrotoksik yang dapat mengakibatkan hipokalemia.

Selain beberapa efek samping yang telah disebutkan, didapatkan juga efek samping dan keluhan yang patut diwaspadai antara lain perubahan perilaku (neurotoksisitas) 
dan keinginan bunuh diri yang disebabkan oleh Sikloserin dan Etionamid, kemudian peningkatan BUN yang disebabkan oleh Kanamisin, Kapreomisin, dan Levofloxacin, lalu terjadinya mual muntah akibat Pirazinamid, Etambutol dan Kanamisin, serta efek samping lainnya. Meskipun frekuensinya rendah, namun perubahan perilaku perlu diwaspadai dalam pengobatan $M D R-T B$. Tingginya potensi neurotoksisitas pada pasien yang menjalani pengobatan $M D R-T B$ telah diantisipasi dengan menambahkan Vitamin B6 atau piridoksin dalam terapi pengobatannya, namun terapi ini tidak menjamin pasien bebas neurotoksisitas.

Adanya efek samping dan keluhan yang dirasakan pasien sangat mempengaruhi kepatuhan dan lama pengobatannya. Terapi pengatasan efek samping ditujukan untuk mengurangi ketidaknyamanan selama pengobatan $M D R-T B$ sehingga pasien dapat menyelesaikan pengobatan. Vitamin B6 telah dimasukkan dalam regimen tetap pengobatan. Neurotoksisitas disebabkan oleh pemberian sikloserin yang diketahui dapat meningkatkan ekskresi piridoksin dalam darah. Pemberian piridoksin bersamaan dengan sikloserin dapat mengurangi potensi seizure, tremor, dan perubahan perilaku lainnya. Namun, piridoksin juga diketahui dapat mengakibatkan neuropati perifer sehingga dosisnya harus disesuaikan. Piridoksin diberikan sebanyak $50 \mathrm{mg}$ pada setiap pemberian 250 mg sikloserin. ${ }^{20}$

Obat Anti Tuberkulosis (OAT) yang digunakan dalam penelitian ini dapat menimbulkan interaksi obat. Interaksi obat yang terjadi pada sikloserin dan etionamid yaitu dapat meningkatkan resiko seizure. Interaksi ini terjadi sebagai akibat dari ekskresi piridoksin secara berlebihan sehingga meningkatkan resiko terhadap perubahan perilaku. Semua pasien $M D R-T B$ dalam penelitian ini menggunakan terapi sikloserin dan etionamid sehingga interaksi ini berpotensi terjadi pada semua pasien. Penanganan terhadap interaksi tersebut dapat dilakukan dengan melakukan monitoring personal terhadap pasien ketika meminum kedua obat tersebut. Kemudian, Sikloserin dan Etionamid dapat diberikan dalam dosis terbagi dalam satu hari sehingga mengurangi efek samping yang tidak diinginkan. ${ }^{21}$

\section{KESIMPULAN}

Penelitian yang telah dilakukan di Poli MDR-TB RSUD Dr. Soetomo Surabaya selama tahun 2016 dapat disimpulkan bahwa jumlah pasien $M D R-T B$ antara laki-laki dan perempuan tidak ada perbedaan yaitu masing-masing 50\%. Domisili pasien $M D R-T B$ luar kota Surabaya lebih banyak daripada wilayah Surabaya. Rentang usia pasien yang mengalami $M D R-T B$ terbanyak adalah di atas 50 tahun. Penyebab $M D R-T B$ terbanyak adalah kasus kambuh. Efek samping terbanyak yang dialami oleh pasien $M D R-T B$ adalah mual muntah.
Terapi akibat efek samping yang paling banyak di terima pasien adalah Omeprazole dan Ranitidine.

Pasien yang menjalani pengobatan $M D R-T B$ diharapkan mencapai target terapi yaitu sembuh. Kesembuhan didukung oleh kepatuhan pasien hingga terpenuhi target dosis minum obat, dan terbukti negatif pada 3 kali pemeriksaan biakan berturut-turut yang berjarak minimal 30 hari selama fase lanjutan. Berdasarkan hasil penelitian dan uraian di atas, efektifitas pengobatan MDR-TB sangat dipengaruhi oleh kombinasi OAT, regimen yang digunakan, dan penanggulangan efek samping akibat OAT. Oleh karena itu dibutuhkan peran farmasis untuk menjamin ketersediaan obat, kualitas obat, dan kesesuaian dosis bagi setiap pasien $M D R-T B$. Meskipun sebagian besar pasien dinyatakan sembuh, namun masih banyak faktor pengobatan yang harus diperhatikan. Ketidakpatuhan menjadi masalah utama dalam pengobatan, sehingga peran dokter, perawat dan farmasi sangat dibutuhkan dalam hal ini. Pasien yang menjalani pengobatan $M D R-T B$ perlu mengetahui bahayanya ketidakpatuhan. Dokter, perawat dan farmasi perlu mendukung kesembuhan pasien agar tidak terjadi DO (drop out), resistensi yang berkelanjutan, maupun kekambuhan.

\section{DAFTAR PUSTAKA}

1. WHO. Global Tuberculosis Report 20th Edition. Vol 20. Switzerland; 2015. doi:10.1017/CBO9781107415324.004

2. RI K. Pedoman Nasional Pengendalian Tuberkulosis. Jakarta: Kementrian Kesehatan Republik Indonesia.; 2014.

3. M-Y C. MDR-TB Patients with Cavitary Lesions and Resistance Pattern of Multidrug Resistan. Inter J Tuberc Lung Dis. 2015;19:525-530.

4. WHO. Multidrug and Extensively Drug-Resistant TB (M/XDR-TB): 2010 Global Report On Surveillance and Response. Switzerland.: WHO Press; 2010.

5. Jonshon, R., Streicher, E.M., Louw, G.E., Warren, R.M., Van Helden, P.D., Victor TC. Drug Resistance in Mycobacterium tuberculosis. Curr Issues Mol Biol. 2006;8(2).

6. Zhang, Y., Yew W-W. Mechanisms of Drug Resistance in Mycobaterium tuberculosis: update 2015. Int J Tuberc Lung Dis. 2015;19(11): 127

7. Da Silva, P.E.A., Palomino JC. Molecular basis and mechanisms of drug resistance in Mycobacterium tuberculosis: classical and new drugs. J Antimicrob Chemother. 2011;66:1417-1430. doi:10.1093/jac/dkr173

8. WHO. Comparion Handbook to the WHO Guidline for the Programmatic Management of Drug-Resistant Tuberculosisi. Management of Drug-Resistant Tuberculosis. Geneva: WHO; 2014.

9. (CDC) C for DC\& P. Prevention and Control of Tuberculosis in Correctional and Detention Facilities MMVR. 2006. 55.

10. Nawas. Prevention \& Control of Tuberculosis in Correctional and Detection Weekly Report. Department of Health and Human Services Center For Disease Control \& Prevention; 2010.

11. WHO. Companion Handbook to The WHO Guidelines for The Programmatic Management Of Drug-Resistant Tuberculosis. Switzerland: WHO Press; 2014.

12. Elmi OS, Hasan H, Abdullah S. Mat Jeab MZ Bin Alwi NN. J. Infect Dev Stries Multi Drug Resistant Tuberculosis and Risk Factors Associated With Its Development; A Retrospective Study. 2015. 
13. Alena Skrahina, Henadz Hurevich, Aksana Zalutskaya, Eugeni Sanalchyk, Andrei Astrauko, Sven Hoffner, valiantsin Rosuvich, Andrei dadu, Bierpaolo de Colombani, Masoud Dara Wayne van Gerert MZ. Multi Drug Resistant Tuberculosis TB Belarus; The Size of The Problem and Associated Risk Factor. Republican scientific and Practical Centre For Pulmonology and Tuberculosisi, Avenue Dolginov Skitrakt 157, 220053 Mink Belarus; 2012.

14. Kell E Dooley, Quafae Lancou, Iragi Grali, Janine Knudsen, My Driss Elmes Saoudi IC and RE. Risk Factors for Tuberculosis Treatment Failure, Defaulth or Relapse and Out Comes of ReTreatment in Morocco. 2011.

15. Meyer K. Tuberculosis, Multi Drug Resistant. Dir Unit Tuberc Oper Policy Res Med Res Counc Pretoris. 2005;25(2).

16. WHO. 6. Management of MDR TB; A Field Guides A Companion Document to Guidelines for Programmatic Management of Drug -Resitant Tuberculosis Integrated Management of Adolescent and Adult Illness (IMAI). Geneva; 2009.
17. Hickjy AJ. Drug Delivery System For Tuberculosis Prevention and Treatment Advances in Pharmaceutical Technology. 2014.

18. Chambers HF, Turner J, Scheeter GF, Kawanura M H Randomized Trial To Optimize Treatment of Multi Drug Resistant. 2005.

19. M.E, Huth AJR and AGC. Mehanism of Aminoglycoside Ototoxicity and Targets of Hair Cell Protection. (Otolaryngology $\mathrm{S}$ of MIJ of, ed.). Department of OtoLaryngology-Head and Neck Surgery, Stanford University; 2011.

20. Health CITC (CITC) and CD of P. Tuberculosis Drug Information Guide 2 Nd Edition.; 2011.

21. Kesehatan BP dan PKK. Riset Kesehatan Dasar. Jakarta: Departemen Kesehatan RI; 2013. 